\title{
KOMODIFIKASI AGAMA TERHADAP PEMBACAAN (KHATAMAN) ALQURAN AIR KEMASAN KH-Q PT. BUYA BAROKAH
}

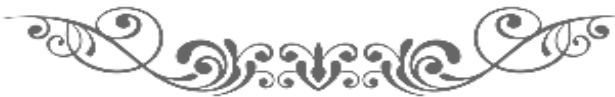

Ahmad Nailul Fauzi

Pascasarjana UIN Sunan Kalijaga Yogyakarta Email: ahnafart93@gmail.com

\begin{abstract}
This paper explains the commodification of religion in the form of the Qur'an recitation on Kh-Q bottled water in Kudus. Commodification is the process of transforming goods and services that once only have value-in-use (for example, the valuein-use of drinks is to quench the thirst, the value-in-use of stories is to communicate or share experiences) into commodities that have value-in-exchange because they can bring profits in the market (for example, after the drink is packed in bottles, after the story is written in a book or novel, or other examples, the commercialization of agriculture to sell food and drama production for commercial broadcasting). The phenomenon in Kudus reflects the existence of a commodity that blends with religion, which is the Qur'an recitation on the production of bottled water under the Kh-Q brand. This study used a descriptive-analytical approach as the analysis instrument for the recitation of Al-Quran (khataman) in Kudus. The results of the analysis in this study show that PT. Buya Barokah has placed religion, through recitation of the Qur'an (khataman), in one of its production processes. Kh-Q water, which is a product of PT. Buya Barokah, has had a dual role. Not only does this water circulate in the economy, but it also has a spiritual function as prayer water. The manifestation of religious commodification is found in the production of bottled water with the spirit of spiritual function of religion in Al-Qur'an recitation (khataman).
\end{abstract}

Keywords: Religious Commodification, Al-Qur'an Recitation, Kh-Q Bottled Water.

\section{Abstrak}

Tulisan ini memaparkan tentang komodifikasi agama terhadap pembacaan Al-Qur'an pada air kemasan Kh-Q di Kudus. Komodifikasi adalah proses transformasi barang dan jasa yang semula hanya memiliki nilai guna (misalnya, nilai guna minuman 
untuk menghilangkan dahaga atau cerita dengan tujuan berkomunikasi atau berbagi pengalaman) menjadi komoditas yang memiliki nilai tukar karena ia bisa mendatangkan keuntungan di pasar (setelah minuman dikemas dalam botol atau setelah cerita dituangkan dalam buku atau novel, ataupun misalnya, komersialisasi pertanian untuk menjual makanan dan produksi drama untuk penyiaran komersial). Fenomena di Kudus mencerminkan adanya komoditas yang berpadu dengan agama, yakni pembacaan Al-Qur'an atas pemproduksian air kemasan dengan brand Kh-Q. Penelitian ini menggunakan pendekatan deskriptif-analitis sebagai instrumen analisa atas fenomena pembacaan Al-Qur'an (khataman) di Kudus. Hasil analisa pada penelitian ini menunjukkan bahwa PT. Buya Barokah telah mendudukan agama, melalui pembacaan Al-Quran (khataman), pada salah satu proses produksinya. Air Kh-Q yang merupakan produk dari PT. Buya Barokah telah mempunyai peran ganda. Air tersebut tidak hanya bersirkulasi pada ekonomi, akan tetapi juga memiliki fungsi spiritual yaitu sebagai air doa. Wujud dari komodifikasi agama ditemukan pada produksi air kemasan dengan semangat fungsi spiritual agama dalam pembacaan AlQur'an (khataman).

Kata Kunci: Komoditfikasi Agama, Khataman Alquran, Air Kemasan $K h-Q$.

\section{PENDAHULUAN}

Fenomena yang terjadi di masyarakat berkaitan dengan Alquran, banyak sekali yang bisa ditemui. Wahyu pertama telah menjadikan asas, bahwa perintah membaca telah nampak sebagai perintah utama. Awal mula Alquran diturunkan, merupakan sebagai petunjuk bagi umat Muhammad yang menjalankan syari'at Islam. Akan tetapi, dengan menyebarnya Islam di seluruh penjuru dunia nampaknya setiap kehidupan orang menggunakan Alquran dengan cara yang unik, serta berbeda dengan satu dan lainnya. ${ }^{1} \mathrm{Hal}$ demikian, terjadi karena adanya dialektika antara Alquran dengan realitas yang akan melahirkan banyak penafsiran. Sehingga pada gilirannya akan

${ }^{1}$ Demikian benar terjadinya di kalangan masyarakat umum, yang mana Alquran tidak hanya sebagai petunjuk hidup (dusturr), tetapi juga sebagai penyembuh bagi penyakit (syifa'), sebagai penerang (nür), dan masih banyak lagi yang dapat ditemui. Ini telah disetujui oleh Farid Esack dalam bukunya yang berjudul The Qurān: a Short Introduction menegaskan, "Alquran fulfills many of function in lives of muslims". Memang benar terjadinya bahwa Alquran mampu memenuhi banyak fungsi di dalam kehidupan orangorang islam. Farid Esack, The Alquran: a Short Introduction, (London: Oneworld Publication, 2002), 16. 
menghadirkan sebuah wacana (discourse) dalam ranah pemikiran, serta timbulnya praksis di dalam realita sosial. ${ }^{2}$

Keyakinan seorang muslim dalam berinteraksi dengan Alquran adalah agar mendapatkan kebahagiaan hidup di dunia maupun di akhirat. Seorang muslim akan mencari petunjuk di dalam Alquran dengan cara membaca, memahami, serta mengamalkan kandungannya, meski membacanya saja sudah termasuk ibadah. Hal ini adalah termasuk resepsi manusia terhadap Alquran dalam kategori hermeneutis. ${ }^{3}$ Tetapi tidak menutup kemungkinan bahkan lebih banyak ditemui, orang tidak lagi memahami arti sebuah ayat -dengan sebab keterbatasan keilmuan masyarakat awam-, melainkan hanya membacanya, seperti yang telah dijelaskan bahwa mereka meyakini sebagai sebuah ibadah. ${ }^{4}$ Misalnya khataman Alquran yang dibacakan pada sebuah wadah (media) air, agar mendapat keberkahan dan manfaat yang lebih, serta kesembuhan (syifä) bagi yang sakit.

Di Kudus, tepatnya di pondok pesantren tahfidz Yanbu'ul Qur'an telah memberi inovasi baru bagi kalangan para pecinta Alquran. Di pondok Yanbu'ul Qur'an ini (selanjutnya dibaca Yanbu'), tidak hanya dididik sebagai penghafal Alquran, akan tetapi bagaimana santri dapat mengelola ekonomi. Terbukti, bahwa pondok Yanbu' mempunyai banyak usaha yang dikelola oleh santri-santi senior, seperti Toko Mubarakatan Tayyibah yang terletak di Jln. Sunan Kudus sebelah utara masjid menara kudus. ${ }^{5}$ Selain itu, ada juga pemproduksian Air mineral kemasan Buya dan Kh-Q yang telah berdiri pada tahun 2008. Uniknya, dalam proses pemproduksian air mineral,

${ }^{2}$ Didi Junaedi, "Memahami Teks, Melahirkan Konteks," Journal of Alquran and Hadith Studies vol.3, no. 1 (2013): 3.

3 Terdapat tiga jenis resepsi yang terjadi terhadap Alquran, yaitu: a) resepsi hermeneutis, b) resepsi sosial-budaya, c) resepsi estetis. Pertama, resepsi hermeneutis merupakan penerimaan terhadap Alquran dalam bentuk pemahaman terhadap isi kandungan Alquran dengan melakukan penerjemahan dan penafsiran terhadap ayat-ayat Alquran. Kedua, resepsi sosial-budaya adalah resepsi yang mengandung makna bagaimana Alquran hidup di dalam kehidupan sosial masyarakat. Ketiga, estetis merupakan respon pembaca terhadap teks Alquran yang dituangkan dalam bentuk keindahan karya seni dan sastra.

${ }^{4}$ Seorang yang yang mengagungkan Alquran tanpa memahami Alquran, oleh Farid Esack digolongkan sebagai seorang pecinta tidak kritis (uncritical lover). Uncritical lover adalah karakter muslim awam, yang dibawa oleh adanya Alquran ke pesawat lain, bersamanya adalah kehadiran Tuhan. Uncritical lover ingin menikmati hubungannya dengan kekasih, tidak mempertanyakan tentang sifat Tuhan atau tentang siapa Tuhan itu. Mereka berkeyakinan, bahwa Alquran adalah obat untuk semua (yang sakit) yang ada di dalam hati. Mereka adalah pecinta buta bahwa Alquran adalah segalanya, tanpa pernah mencoba meragukan atau menanyakan tentang Alquran, seperti memajang beberapa ayat-ayat Alquran dengan tujuan agar selamat dari ancaman bahaya atau mendapat keberkahan. Farid Esack, The Qur'an: A User's Guide: a Guide to Its Key Themes, History and Interpretation, (t.tp: Oneworld, 2005), 2.

5 Observasi awal penulis. 
sebelumnya telah ada pembacaan (khataman) Alquran yang dilakukan oleh para santri Yanbu'. Pembacaan (khataman) Alquran ini dikhususkan pada kemasan label Kh-Q. Demikian, dalam pembacaan (khataman) Alquran adalah kewajiban santri Yanbu' sebagai bentuk tirakatan setelah hafal 30 juz. ${ }^{6}$

Dari penyataan di atas, penulis mempunyai ketertarikan untuk mengkaji atas Pengelolaan Air Kemasan Kh-Q, yang mana brand tersebut terdapat sebuah proses yang sebelumnya telah dibacakan (khataman) Alquran yang dilakukan para santri Yanbu' di pondok. Sehingga model demikian dapat dikualifikasikan sebagai living Qur'an atas pembacaan Alquran pada sebuah media (air). Lebih jauh lagi, penulis ingin mengetahui dan meneliti bagaimana proses khataman Qur'an dalam produksi air kemasan Kh-Q, serta bagaimana komodifikasi agama atas pembacaan (khataman) Alquran dalam Air Kemasan Kh-Q.

\section{PEMBAHASAN}

\section{Komodifikasi Agama}

Komodifikasi (commodification) adalah titik masuk awal untuk menteorisasikan ekonomi politik komunikasi. Vincent Mosco sebagaimana yang dikutip oleh Idi Subandy Ibrahim, dan Bachruddin Ali Akhmad, mendefinisikan komodifikasi sebagai proses mengubah barang dan jasa, termasuk komunikasi, yang dinilai karena kegunaannya, menjadi komoditas yang dinilai karena apa yang akan mereka berikan di pasar. Mosco menjelaskan komodifikasi merupakan sebuah proses yang melibatkan perubahan atau transformasi pesan media menjadi produk yang dapat dipasarkan. Di samping itu, komunikasi menjadi dagangan yang paling digemari di era kapitalisme ini sebab nilai surplus yang dimiliki produkproduk komunikasi. Produk komunikasi terdiri dari simbol-simbol yang dapat membentuk kesadaran. Kesadaran inilah yang dimanfaatkan kapitalis untuk melanggengkan kekuasaanya. ${ }^{7}$ Komodifikasi adalah proses transformasi barang dan jasa yang semula dinilai gunanya (misalnya, nilai guna minuman untuk menghilangkan dahaga, cerita untuk berkomunikasi atau berbagi pengalaman), menjadi komoditas yang bernilai karena ia bisa mendatangkan keuntungan di pasar setelah dikemas minuman dalam botol ataupun misalnya, komersialisasi pertanian untuk menjual makanan dan produksi drama untuk penyiaran komersial. Adam Smith dan penganjur

${ }^{6}$ Wawancara dengan Saudara Abdurrahman Wahid (santri Ponpes Yanbu'ul Quan), pada tanggal 17 Maret 2019.

7 Idi Subandy Ibrahim, dan Bachruddin Ali Akhmad, Komunikasi dan Komodifikasi: Mengkaji Media dan Budaya dalam Dinamika (Jakarta: Yayasan Putra Obor Indonesia, 2014), 17. 
ekonomi politik klasik telah membedakan antara produk yang nilainya muncul dari pemuasan keinginan dan kebutuhan khusus manusia, yakni nilai guna (use value), dan produk yang nilainya didasarkan atas apa yang bisa ia berikan dalam pertukaran, yakni nilai tukar (exchange value). Komoditas adalah bentuk tertentu dari produk ketika produksinya terutama diorganisasikan melalui proses pertukaran. Komodifikasi adalah proses perubahan nilai guna menjadi nilai tukar. ${ }^{8}$

Perkembangan teknologi, informasi, urbanisasi serta pertumbuhan ekonomi menjadi faktor pendorong komodifikasi serta mempengaruhi cara individu mengekspresikan keimanannya. Dengan melihat masa sebelumnya, munculnya komoditas agama, orang Islam sudah tidak jarang lagi menggunakan label keislamannya dalam mengembangkan nilai atau keyakinannya. Dalam kehidupan sehari hari misalnya, kita melihat bagaimana orang berlangganan sms doa, memakai busana muslim, mengkonsumsi novel atau film Islami, menabung di bank syariah, melakukan umroh, menghadiri ESQ hingga membeli pasta gigi yang berlabel Islam. Maraknya komodifikasi Islam ini menurut Fealy dan Sally menjadi saran diterimanya kehadiran Islam di ranah public secara taken for granted. Lebih jauh Fealy dan Sally menjelaskan bahwa konsumsi terhadap produk Islam juga terkait degan identitas individu. Derasnya arus globalisasi berdampak pada terjadinya destabilized identy ketika agama menjadi salah satu alternatif untuk menciptakan identitas baru. Artinya bahwa konsumsi terhadap barang islami dalam terminology Bourgeois dijadikan sebagai symbolic capital untuk mengukuhkan identitas serta mempertahankan posisi individu muslim dalam kelas sosialnya. Konsumsi terhadap produk-produk islami seringkali menunjukan status sosial yang tinggi dalam masyarakat. ${ }^{9}$

Menurut Kitiarsa sebagaimana yang dikutip oleh Idi Subandy Ibrahim, dan Bachruddin Ali Akhmad megatakan bahwa komodifikasi agama merupakan kontruksi historis dan kultural yang kompleks, sekalipun demikian ciri komersial mereka begitu nyata. Mereka direproduksi dalam konteks kebudayaan tertentu dan kemudian mempersyaratkan kerangka kultural untuk mempertegas signifikansi simbolik sosio-ekonomi mereka. Komodifikasi merupakan sebuah proses yang benar-benar dimunculkan dan disertakan dalam saluran ekonomi pasar lokal-global dan ledakan agama postmodern. Komodifikasi memang tidak bertujuan memproduksi bentuk dan gerakan agama baru yang berlawanan dengan keyakinan dan praktik agama sebelumnya, namun komodifikasi akan mendudukan agama sebagai barang yang melaluinya fungsi spiritual agama menjadi komoditas yang

8 Idi Subandy Ibrahim, dan Bachruddin Ali Akhmad, Komunikasi dan Komodifikasi: Mengkaji Media dan Budaya dalam Dinamika,18.

9 Idi Subandy Ibrahim, dan Bachruddin Ali Akhmad, Komunikasi dan Komodifikasi: Mengkaji Media dan Budaya dalam Dinamika, 18. 
layak dikonsumsi dalam masyarakat. Di kalangan umat Islam Indonesia "komodifikasi agama" muncul dalam bentuk perayaan konsumsi massa pada hari raya keagamaan (seperti saat puasa Ramadhan atau Idul fitri) dan juga fenomena mereka menyebut diri ulama atau ustadz atau penceramah agama yang notabene menganjurkan umat bersikap sederhana dan menahan diri tetapi malahan dengan bangga menjadi bintang iklan untuk produk konsumsi di layar televisi, spanduk, dan papan reklame. Komodifikasi agama juga bisa ditelaah dalam bentuk komodifikasi zakat dan komodifikasi haji yang dijadikan bisnis untuk mengeruk keuntungan bagi beberapa kelompok tertentu dengan memanfaatkan kepolosan dan kebaikan hati umat Islam. ${ }^{10}$

Karl Marx mengawali Capital dengan analisis tentang komoditas karena dia menemukan bahwa komoditas telah menjadi bentuk paling jelas, representasi paling eksplisit, dari produksi kapitalis. Kapitalisme secara harfiah tampil sebagai koleksi komoditas yang luar biasa besarnya. Salah satu kunci analisis Marxian adalah mendekonstruksi komoditas untuk menentukan apa makna yang tampak, untuk membongkar relasi-relasi sosial yang membeku dalam bentuk komoditas. Sebagaimana telah didokumentasikan oleh Jhally yang dikutip oleh Idi Subandy Ibrahim, dan Bachruddin Ali Akhmad, didalam salah satu dari sedikit analisis dalam bentuk komoditas dalam literatur komunikasi, Marx mengambil pandangan yang luas baik terhadap komoditas maupun terhadap makna nilai guna. Bagi Marx sebagaimana yang dikutip oleh Idi Subandy Ibrahim, dan Bachruddin Ali Akhmad, komoditas berasal dari rentang luas kebutuhan, baik fisik maupun budaya dan yang gunanya dapat didefinisikan dalam berbagai cara. Pandangan Marx jelas bukan tanpa kritik. Beberapa kritikus yang merasa tidak puas dengan formulasi Marx tersebut, berpendapat bahwa pembedaan antara nilai guna dan nilai tukar lebih mengaburkan ketimbang menjelaskan. Misalnya, menurut Sahlins sebagaimana yang dikutip oleh Idi Subandy Ibrahim, dan Bachruddin Ali Akhmad, Marx mengakui karakter sosial semua nilai tetapi cenderung untuk menaturalisasikan nilai guna. Vincent Mosco mengupas kembali apa yang disebut Marx sebagai (onion skin) penampilan komoditas yang menyingkapkan sistem produksi. Dalam pandangan Mosco sebagaimana yang dikutip oleh Idi Subandy Ibrahim, dan Bachruddin Ali Akhmad, proses komodifikasi memiliki dua arti penting bagi penelitian komunikasi. ${ }^{11}$

Pertama, proses dan teknologi komunikasi telah berkontribusi pada proses umum komodifikasi dalam ekonomi secara keseluruhan. Misalnya,

10 Idi Subandy Ibrahim, dan Bachruddin Ali Akhmad, Komunikasi dan Komodifikasi: Mengkaji Media dan Budaya dalam Dinamika, 18.

11 Idi Subandy Ibrahim, dan Bachruddin Ali Akhmad, Komunikasi dan Komodifikasi: Mengkaji Media dan Budaya dalam Dinamika, 19. 
perbaikan saluran komunikasi dalam bisnis pakaian, khususnya dalam pengenalan teknologi komputer dan telekomunikasi global, telah memperluas informasi mengenai seluruh sirkuit produksi, distribusi, dan penjualan pakaian. Praktik dan teknologi komunikasi juga berkontribusi pada proses komodifikasi secara umum dalam masyarakat. Misalnya, pengenalan komunikasi komputer memungkinkan semua perusahaan, tidak hanya perusahaan komunikasi, memegang kendali lebih besar terhadap seluruh proses produksi, distribusi, dan pertukaran, sehingga memungkinkan para pedagang eceran untuk memonitor tingkatan penjualan dan ketersediaan dengan ketepatan yang belum pernah dicapai sebelumnya.

Kedua, proses komodifikasi yang berjalan dalam masyarakat secara keseluruhan mempenetrasi proses komunikasi dan institusi, sehingga perbaikan dan kontradiksi dalam proses komodifikasi sosial mempengaruhi komunikasi sebagai suatu praktik sosial. Misalnya, kecenderungan internasional untuk melakukan liberalisasi dan privatisasi usaha, telah mengubah institusi telekomunikasi dan media publik serta media yang digerakan Negara diseluruh dunia menjadi usaha privat. Hal ini telah mengubah komunikasi layanan publik dengan komitmen sosial untuk akses universal dan konten yang merefleksikan masyarakat luas menjadi kominukiasi komersial yang menyediakan akses bagi mereka yang bisa membukanya dan konten yang menyerahkan khalayak ke para pengiklan. ${ }^{12}$

\section{Tipe-tipe Komodifikasi}

Secara umum, ada beberapa tipe komodifikasi yang penting bagi komunikasi yaitu komodifikasi isi, komodifikasi khalayak, komodifikasi tenaga kerja, komodifikasi masa kanak-kanak dan komodifikasi nilai. Pertama, Komodifikasi Isi. Menjadi pusat perhatian kajian ekonomi politik media dan komunikasi. Ketika pesan atau isi komunikasi diperlakukan sebagai komoditas, ekonomi politik cenderung memusatkan kajian pada konten media dan kurang pada khalayak media dan tenaga kerja yang terlibat dalam produksi media. Tekanan pada struktur dan konten media ini bisa dipahami terutama bila dilihat dari kepentingan perusahaan media global dan pertumbuhan dalam nilai konten media.

Kedua, Komodifikasi Khalayak. Ekonomi politik menaruh beberapa perhatian pada khalayak, khususnya dalam upaya untuk memahami praktik umum dengan cara pengiklan membayar untuk ukuran dan kualitas (kecendungan untuk konsumsi) khalayak yang dapat diraih surat kabar, majalah, website, radio, atau program televisi.

Ketiga, Komodifikasi Tenaga Kerja. Selanjutnya untuk mengkaji proses komodifikasi isi dan khalayak media, penting untuk

12 Idi Subandy Ibrahim, dan Bachruddin Ali Akhmad, Komunikasi dan Komodifikasi: Mengkaji Media dan Budaya dalam Dinamika, 17. 
mempertimbangkan komodifikasi tenaga kerja media. Tenaga pekerja komunikasi yang juga di komodifikasi sebagai buruh upahan telah tumbuh secara signifikan dalam pasar kerja media. Dalam menghadapi komodifikasi ini, para pekerja media telah menanggapi dengan menggalang orang-orang dari media berbeda, termasuk jurnalis, professional penyiaran, dan spesialis teknis dalam film, video, telekomunikasi dan sektor jasa computer, untuk bergabung dalam serikat pekerja dan organisasi-organisasi pekerja lain yang diklaim mempresentasikan segmen terbesar dari tenaga kerja komunikasi (McKercher 2002; Mosco dan McKercher 2008). Ini adalah bentuk perlawanan terhadap komodifikasi, seperti yang dibahas dalam buku ini.

Keempat, "Komodifkasi Nilai". Komodifikasi nilai ini menjelma dalam proses komodifikasi yang menguat dalam dunia pendidikan dan agama. Graham Ward, seorang profesor etika dan teologi kontekstual di Universitas Manchester, telah menulis esai kritis "The Commodification of Religion, or The Consummation of Capitalism". Di dalam esainya, Ward menjelaskan bahwa Marx tidak menggunakan istilah komodifikasi, melainkan ia merujuk pada berbagai konsep yang digunakan Marx untuk mendeskripsikan pengalaman manusia mengenai nilai dibawah rezim baru kapitalisme. Komodifikasi, selanjutnya, hampir berhubungan dengan reifkasi (Verdinglichung dalam istilah Marx). Seperti dijelaskan Ward, komodifikasi adalah apa yang terjadi dengan benda-benda dalam kapitalisme, sementara reifkasi adalah apa yang secara stimulant terjadi pada pribadi-pribadi. Pada hakikatnya, tidaklah wajar ketika benda-benda diubah menjadi suatu yang personal dan pribadi-pribadi diubah menjadi benda-benda.

Pada tahun 1970 Jean Baudrillard pertama kali menerbitkan The Consummer Society, banyak yang telah menulis tentang khusus yang diajukan masyarakat konsumen terhadap nilai-nilai dan keyakinan agama. Untuk sebagian besar, mereka mengkritik konsumerisme sebagai ideology yang menyebarkan seperangkat nilai yang saling bertentangan atau berkompetisi. Dalam bukunya, Cosuming Religion, Vincent Miller berpendapat sebagaimana yang dikutip oleh Idi Subandy Ibrahim, dan Bachruddin Ali Akhmad, bahwa bahaya nyata yang dilakukan oleh budaya konsumen adalah karena ia menjangkiti segenap kapasitas kita untuk menerima apa yang bernilai. ${ }^{13}$

Agama menurut Kamus besar Bahasa Indonesia (2008), agama merupakan sistem atau kepercayaan kepada Tuhan, atau juga disebut dengan nama dewa atau nama lainnya dengan ajaran kebaktian dan kewajibankewajiban yang berkaitan dengan kepercayaan tersebut. Agama berasal dari kata din dari bahasa Arab dan kata religi dari bahasa Eropa. Agama berasal

13 Idi Subandy Ibrahim, dan Bachruddin Ali Akhmad, Komunikasi dan Komodifikasi: Mengkaji Media dan Budaya dalam Dinamika, 20. 
dari dari kata Sankrit. Satu pendapat mengatakan bahwa kata itu tersusun dari dua kata, " $a "=$ tidak dan "gam" = pergi, jadi tidak pergi, tetap ditempat, diwarisi turun-temurun. Agama memang mempunyai kitab-kitab suci. Selanjutnya dikatakan lagi bahwa gam berati tuntutan. Memang agama mengandung ajaran-ajaran yang menjadi tunt ut an hidup bagi penganutnya.

Din dalam bahasa Semit berarti undang-undang atau hukum. Dalam bahasa Arab kata ini mengandung arti menguasai, menundukkan, patuh, hutang, balasan, kebiasaan. Agama memang membawa peraturan-peraturan yang merupakan hukum, yang harus dipatuhi orang. Agama selanjutnya memang menguasai diri seseorang dan membuat ia tunduk dan patuh kepada Tuhan dengan menjalankan ajaran-ajaran agama. Agama lebih lanjut lagi membawa kewajiban-kewajiban yang kalau tidak dijalankan oleh seseorang menjadi hutang baginya. Paham kewajiban dan kepatuhan membawa pula kepada paham balasan. Yang menjalankan kewajiban dan patuh akan mendapatkan balasan baik dari Tuhan. Yang tidak menjalankan kewajiban dan yang tidak patuh kepada Tuhan akan mendapat balasan yang tidak baik. $^{14}$

\section{Proses Pembacaan (khataman) Qur'an}

Alquran di Indonesia awal sesungguhnya bereperan sebagai sarana bacaan di saung ataupun langgar desa. Berjalannya waktu, masyarakat Indonesia sudah tidak hanya membaca Alquran melainkan mencoba memahami makna yang terkandung di dalam Alquran sehingga berkembang dan menghasilkan karya tafsir yang dikenal. Akan tetapi, hal lain yang tidak bisa ditutupi adalah sebuah peristiwa yang relevan berkenaan dengan Alquran, yakni khataman (sempurna) Alquran di sebuah majlis. Fenomena pembacaan Alquran di masyarakat yang dapat dilihat, sangatlah beragam modelnya. Sebab setiap daerah dapat dipastikan mempunyai adat serta tradisi yang berbeda dengan yang lain. Misalnya, pembacaan ayat-ayat Alquran dalam Upacara Peret Kandung di desa Poteran Kecamatan Talango kabupaten Sumenep Madura. Dalam upacara tersebut ayat-ayat Alquran dibaca sebagai media doa untuk memohon keberkahan dan keselamatan. Demikian adalah bentuk upaya yang dilakukan masyarakat sebagai media perantara antara hamba dan Tuhan agar lebih dekat dan selalu ingat kepada sang Pencipta. ${ }^{15}$ Lebih lagi di pesantren, ada faktor yang harus dijalankan oleh para santri, membaca Alquran atas harapan keberkahan dan Keselamatan. Faktor lain, adanya perintah atau aturan pesantren sebagai

${ }^{14}$ Harun nasution, Islam ditinjau dari dari berbagai Aspeknya (Jakarta: Universitas Indonesia Press, 1985), 9-13.

15 Rafi'uddin, Pembacaan Ayat-Ayat Alquran dalam Upacara Peret Kandung di desa Poteran Kec. Talango kab. Sumenep Madura (Yogyakarta: Fakultas Ushuluddin UIN Sunan Kalijaga, 2013), 82. 
bentuk ta'zim kepada kiai, yang lambat laut menjadi sebuah tradisi. ${ }^{16}$ Dalam sebuah hasil penelitian, atas respon perintah membaca Alquran di Padukuhan Srumbung, Pleret, Bantul, masyarakat telah menyatakan bahwa demikian adalah hal keharusan yang mesti dilakukan oleh umat Islam itu sendiri. ${ }^{17}$

Hal di atas tentu ada relevansi terhadap kejadian yang pernah ada di masa Nabi sendiri. Ketika Nabi mengalami demam, menjelang beliau wafat, beliau menggunakan air untuk merendam sejenak penyakitnya. Beliau bersabda, "Siramakan air kepadaku dari tujuh qirbah yang belum dilepas ikatannya, mudah-mudahan aku bisa memberi pesan kepada orang-orang." Dari Abu Nu'aim yang meriwayatkan Hadis Anas dan menyebutkan secara marfü, "jika kalian demam guyurlah tubuh dengan air sejuk (tidak dingin es, tidak juga hangat) selama tiga hari pada waktu menjelang subuh." Dalam doa istiftạh disebutkan, "Ya Allah, cucilah diriku dari dosa-dosaku dengan es, air dan embun. Air adalah sumber kehidupan." Allah menegaskan dalam Q.S. al-Anbiyā': 30 Artinya: "Dan dari air Kami jadikan segala sesuatu yang hidup. Maka mengapakah mereka tidak juga beriman?' Allah sudah menegaskam bahwa kehidupan ini berasal dari Air. Maka air juga yang menjadi penopang kehidupan. ${ }^{18}$ Orang bisa bertahan hidup bermingguminggu tanpa makan tapi ia tak akan mampu hidup seminggu saja tanpa air. Bukan hanya manusia tapi makhluk hidup di bumi ini butuh air untuk bertahan hidup. Allah berfirman dalam Q.S. Al-Baqarah: 22, artinya "Dialah Yang menjadikan bumi sebagai hamparan bagimu dan langit sebagai atap, dan Dia menurunkan air (hujan) dari langit lalu Dia menhasilkan dengan hujan itu segala buah-buahan sebagai rizki untukmu..."

Allah juga pernah menguatkan genggaman kaki orang-orang beriman dengan air hujan. Dalam Q.S. Al-Anfal: 11, Artinya: “...dan Allah menurunkan kepadamu hujan dari langit untuk menyucikan kamu dengan hujan itu dan menghilangkan dari kamu gangguan-gangguan syaithan dan untuk menguatkan hatimu dan memperteguh dengannya telapak kaki (mu)..." Namun sayang, bahwa manusia masih sangat kurang memanfaatkan potensi air ini demi kebutuhan hidupnya. Seringkali seseorang tidak sadar bahwa tubuhnya butuh pasokan air dalam kondisi normal antara dua hingga tiga liter air perharinya. Meski sudah banyak kampanye memasyarakatkan minum air putih minimal 18 gelas sehari, tapi lebih banyak yang abai

16 Vitri Nurawalin, Pembacaan Alquran dalam Tradisi Mujahadah Sabihah Jumu'ah :Studi Living Alquran di Pondok Pesantren Sunan Pandanaran, Sleman, Yogyakarta (Yogyakarta: Fakultas Ushuluddin UIN Sunan Kalijaga, 2014), 90.

17 Lihat, Moh. Ali Wasik, Fenomena Pembacaan Alquran dalam masyarakat Padukuhan Srumbung, Pleret, Bantul (Yogyakarta: Fakultas Ushuluddin UIN Sunan Kalijaga, 2005), 80.

18 Q.S. Al-Anbiyaa: 30. 
terhadap hal tersbut. Padahal sebagai muslim, mestinya tahu betul bahwa air putih adalah salah satu dari komoditi al-tibb al-Nabawi yang berfungsi menjaga kesehatan. Bahkan saat berbuka, seandainya seseornag tak mendapatkan kurma, maka ia dianjurkan untuk meneguk air putih. Meminum air minum biasa secara benar, memurnikan tubuh manusia. Hal itu membuat usus besar bekerja dengan lebih efektif dengan cara membentuk darah baru, dalam istilah medis dikenal sebagai aematopaises.

Pembacaan Alquran atau lebih tepatnya khataman Alquran merupakan bentuk dari tradisi pesantren tahfiz, yang berkembang di masyarakat luas. Khataman ini biasanya dilakukan secara hafalan (bi alghayb) 30 juz, meski juga diketahui bentuk model khataman lain, yaitu dengan membaca muṣhaf (bi al-nazar), yang dibagikan setiap juznya, pada banyaknya orang yang akan akan mengikuti khataman. ${ }^{19}$ Dalam lingkup masyarakat, khataman Alquran umumnya dilaksanakan ketika dan pada salah seorang warga mempunyai hajat, misalnya dalam hajat walimah khitan (sunatan), tujuh hari setelah wafat, dan bentuk syukuran lain yang ada dalam tradisi di sebuah daerah. ${ }^{20}$ Khataman Alquran juga sering dijumpai di bulan Ramadhan, dapat ditemui di masjid-masjid dan surau-surau. Masyarakat meyakini akan pahala yang besar didapati ketika membaca Alquran di bulan tersebut. Menurut mereka, itulah investasi akhirat yang perlu dicari dan digunakan sebagai penyelamat. ${ }^{21}$ Sedikit berbeda misalnya, di kalangan pondok pesantren Alquran tidak hanya dibaca saja, akan tetapi juga dikaji. Biasanya, setiap bulan Ramadhan salah seorang kiai akan membacakan tafsir Alquran sampai hatam. Ia akan membaca secara cepat serta memaknai sebuah tafsir tersebut. ${ }^{22}$

\section{PT. Buya Barokah dan Air Kemasan Kh-Q}

Yayasan Arwaniyyah yang beralamatkan di Jalan K.H. M. Arwani Kelurahan Kajeksan No.24 Kudus, yaitu simpang tujuh kota Kudus ke barat menuju arah Sunan Kudus, sampai di Sunan Kudus terus ke utara sampai ke Madrasah Banat lurus terus belok ke utara kurang lebih tiga puluh meter,

19 Observasi penulis.

20 Penulis melihat, masyarakat mempunyai sebuah inovasi melaksanakan Khataman Alquran yang sangat bervarian di masyarakat. Pengalaman penulis, pernah mengikuti undangan Khataman Alquran yang dilaksanakan setiap sebulan sekali di rumah warga, dengan tujuan mengirim doa kepada ahli waris yang telah meninggal. Dalam kesempatan lain, ada salah seorang warga mengundang penghafal Alquran untuk Khataman, agar anak yang dikhitan selamat tanpa ada arang melintang.

${ }^{21}$ Observasi penulis.

22 Penulis pernah mengikuti kajian pembacaan tafsir di bulan puasa. Orang-orang sering mengistilahkan dengan ngaji posonan, yaitu mengaji di bulan puasa dengan salah seorang Kiai dalam kitab yang ditentukan hingga khatam. Salah satu kitabnya adalah Tafsir Jalālayn. 
Yayasan Arwaniyyah juga memiliki badan usaha yang disebut BUYA (Badan Usaha Yayasan Arwaniyyah). ${ }^{23}$

Salah satu usaha Yayasan Arwaniyyah adalah PT. BUYA BAROKAH (Devisi Air Minum). Tepatnya pada tahun 2008 PT. BUYA BAROKAH (Devisi Air minum) mengelola usaha Air Minum dengan logo BUYA, merupakan awal perusahaan untuk memenuhi pasokan air minum dilingkungan yayasan Arwaniyyah (untuk kalangan sendiri). Di sisi lain perusahaan melihat keprihatinan terhadap masyarakat yang datang ke Yayasan Arwaniyyah dengan keadaan yang kurang sehat untuk mengharapkan berkah doa Kiai (Ngalap berkah) melalui perantara air yang sudah diberi doa. Melalui air doa tersebut mereka berharap diberi kesehatan oleh allah Swt. Maka munculah ide perusahaan untuk meluncurkan produk air minum yang sudah diberi doa sebagai air minum kesehatan yang dijadikan perantara (wasìlah) Kiai, agar masyarakat tidak kecewa karena tidak bisa bertemu dengan Kiai. ini merupakan salah satu langkah yang di upayakan perusahaan dan yayasan agar masyarakat yang datang merasa nyaman. ${ }^{24}$

Beranjak dari keprihatinan dan permintaan masyarakat, maka munculah produk air minum yang diberi doa dengan merek Kh-Q (Khataman Alquran). Produk air minum Kh-Q mulai diluncurkan pada tanggal 10 November 2011, merupakan produk air minum yang ditilawahkan dengan tiga puluh juz Alquran dan ditambahkan dengan do'a Khataman Alquran yang lebih dikenal dengan air do'a. Di samping itu juga melalui proses tekhnologi R.O, Uv. ${ }^{25}$ Selanjutnya, proses khataman dilakukan di dua lokasi, yakni pondok pesantren Yanbu'ul Qur'an dan di tempat pemproduksian air mineral yaitu PT. Buya Barokah. Proses dilaksanakan para santri Yanbu' yang bertempat di makam Mbah Arwani Amin. ${ }^{26}$ Di dalam proses

${ }^{23} \mathrm{http}$ ://www.arwaniyyah.com/index.php/2012-06-05-18-59-41/123-profil-yayasanarwaniyyah. rabu, 12 Maret 2019. Pukul 20.59

24 Wawancara dengan Saudara Abdurrahman Wahid (santri Ponpes Yanbu'ul Quan), pada tanggal 17 Maret 2019.

${ }^{25}$ Wawancara dengan bpk Ashef Maftuch (Manajer Utama PT. Buya Barokah), Kudus: di kantor PT. Buya Barokah, tanggal 17 Maret 2019.

${ }^{26}$ K.H. Muhammad Arwani merupaka pendiri perguruan tarekat Naqsyabandiyyah Kholidiyyah, yang telah mengharumkan kota lahirnya yakni Kudus. Mbah Arwani belakangan semakin dikenal dan dikenang sebagai seorang muballigh yang sesungguhnya, seorang yang 'alim, sekaligus Khālifah Naqsyabandiyyah yang gigih di abad kontemporer ini. Setelah dari tangannya seorang diri lahir banyak ulama. Salah satu keahliannya yang sangat langka adalah menjadi guru tahfiz Alquran dan ilmu Qiä'at Sab'ah dari hasil berguru kepada K.H. Munawwir (w.1942 M) Krapyak Bantul, selama sembilan tahun (1932-1941 M). Ia merupakan pendiri pondok tahfiz Yanbu'ul Alquran Kudus yang berdiri pada tahun 1962 M di Desa kajeksan. Satu kilometer sebelah utara masjid Menara Kudus. Lihat lebih 
pembacaan telah disediakan beberapa galon yang telah terisi air. Akan tetapi, proses tersebut dilakukan ketika ada event tertentu, sebab nantinya air akan dibagikan sebagian kepada para tamu yang hadir di sebuah acara dan sebagian lain dimasukkan ke dalam sumur produksi air. Adapun proses khataman yang dilakukan di tempat produksi, dilakukan setiap hari secara bergantian. ${ }^{27}$ Air kemasan $120 \mathrm{ml}$ jika disajikan di suasana lebaran sangatlah tepat, ukuran sesuai dan jika diminum tidak terlalu banyak takaran, cukup seminit saja airnya sudah habis. Apalagi jika air yang diminum telah dibacakan alquran dari para santri hăfiz Alquran maka menjadi daya tarik tersendiri bagi sebagian warga di wilayah Kudus, Pati serta Demak. ${ }^{28}$

Itulah air kemasan merk Kh-Q produk dari Kudus, Jawa Tengah yang diproduksi oleh PT. Buya Barokah Kudus, Jawa Tengah, Indonesia. Bagi para santri atau alumni ponpes Yanbu'ul Qur'an tentunya merk ini tersedia saat jelang lebaran hingga bada sawal atau 7 hari setelah lebaran, dan sepertinya syarat utama dibandingkan merk air kemasan lainnya. Air minum Kh-Q ini diproses dengan R.O, Uv, dan Ozon, apalagi ditambahkan bacaan Alquran menambah sugesti bagi warga di wilayah Kudus, Jepara dan Demak serta warga Kabupaten lainnya, memang air minum ini belum meluas seperti merk kompetitor lainnya yang sudah merambah hingga ke nusantara ini. Contohnya merk Vit, Aqua, Adi atau merk lainnya. Produk $\mathrm{Kh}-\mathrm{Q}$ ada beberapa isi yang dijual ke pasaran yakni isi $120 \mathrm{ml}, 220 \mathrm{ml}, 600 \mathrm{ml}$. Namun saat musim lebaran atau Idhul Fitri, yang laku keras adalah kemasan $120 \mathrm{ml}$, di samping kecil, pas dengan ukuran beberapa tegukan atau hisapan lewat sedotan saja sudah habis. Air kemasan ini sudah punya ijin BPOM RI dan tertulis di setiap packing botolnya yakni BPOM RI MD.265211004254, bahkan ada pesan khusus di kemasannya yang bertulisakan disimpan di tempat yang sejuk, hindari dari sinar matahari langsung dan benda-benda berbau tajam. Isi per kardus relatif sama dengan kemasan air yang lain yakni $48 \times 220 \mathrm{ml}$ atau $48 \times 120 \mathrm{ml}$. Mungkin isi kemasan seperti ini menjadi cara memudahkan menghitung dan menaruh air kemasan ini agar mudah di bawa, mudah mempacking ke dalam kardus termasuk mudah menghitung keuntungan yang di dapat tentunya. ${ }^{29}$

Promosi dari mulut ke mulut dan terdapat prosesi bacaan Alquran menjadi media paling cepat dan memiliki posisi tawar yang menjanjikan, wajar jika produk Kh-Q walaupun belum lama produksinya, namun cepat

legkapnya di buku Ahmad Dimyati, Dakwah Personal: Model Dakwah Kaum Naqsyabandiyah (Yogyakarta: Deepublish, 2016), 52-53.

27 Wawancara dengan Saudara Abdurrahman Wahid (santri Ponpes Yanbu'ul Quan), pada tanggal 17 Maret 2019.

28 Wawancara dengan Saudara Abdurrahman Wahid (santri Ponpes Yanbu'ul Alquran), pada tanggal 17 Maret 2019.

29 Wawancara dengan Saudara Abdurrahman Wahid (santri Ponpes Yanbu'ul Quan), pada tanggal 17 Maret 2019. 
melekat di hati warga, tidak jarang jika sejumlah toko sembakao atau warung kelontong di wilayah Kudus, Jepara, dan Demak menyediakan air kemasan ini dan harga eceranpun berani sama dengan merk Aqua atau Vit, bahkan warga di sana lebih melirik merk Kh-Q. ${ }^{30}$ Jika pantauan di Kota Telor asin Brebes Jawa Tengah, sementara yang masih unggul dalam daya beli air kemasan adalah merk Aqua, Vit, Adi, dan merk lainnya. Namun spesifik khusus seperti Kh-Q ini sepertinya menjadi branding menarik bagi warga muslim di Indonesia yakni telah dibacakan Alquran dari para hăfiz yang jadi santri di pondok pesantren terbesar di Kudus tersebut. ${ }^{31}$

\section{Teknologi R.O. UV, Post Carbon, Bio Ceramic, Bio Magnetik}

Teknologi R.O. (Reverse Osmosis) merupakan teknologi pemurnian air yang mutakhir saat ini. Reverse Osmosis menyaring air dari tingkat yang paling kecil yaitu 1/10.000 mikron atau setaran dengan sehelai rambut dibagi 1 juta. Dengan sangat kecilnya membran R.O. menyaring air serta menghasilkan air yang sangat murni, sehingga virus, bakteri dan unsur logam yang terkandung didalamnya ikut tersaring. ${ }^{32}$

\section{Carbon, Bio Ceramic dan Bio Macgnetic}

Post Carbon merupakan elemen yang berfungsi untuk menjamin kualitas air dengan memperbaiki rasa, bau dan sebagainya. Bio Ceramic berfungsi untuk memecah molekul-molekul air dengan sinar Far Infrared untuk meningkatkan kesehatan dan ketahanan tubuh dan dapat mengurangi efek dari radiasi sinyal Hand Phone. Bio Macgnetic berfungi menambah energi magnetik pada air yang memiliki sifat posotif dan baik untuk terapi penyakit dalam, serta dapat meningkatkan vitalitas tubuh.

\section{Visi dan Misi Perusahaan}

Visi perusahaan yaitu ingin menjadi perusahaan air minum yang aman dikonsumsi dan menyehatkan, serta memberikan manfaat bagi masyarakat indonesia dengan memperhatikan nilai-nilai etika bisnis Islam.

Misi perusahaan yaitu dengan meluncurkan produk Air minum yang diproses dengan tekhnologi canggih sehingga produk yang dikeluarkan perusahaan aman untuk dikonsumsi seperti merek Buya, perusahaan juga memiliki produk unggulan dengan merek Kh-Q (Khataman Alquran) yang

30 Wawancara dengan Saudara Abdurrahman Wahid (santri Ponpes Yanbu'ul Quan), pada tanggal 17 Maret 2019.

${ }^{31}$ https://www.kompasiana.com/penaulum/5b27118fbde57517e3046eb2/berkahbacaan-alquran-di-air-kemasan-Kh-Q. diakses pada Tanggal 25 Mei 2019.

32 Wawancara dengan bpk Ashef Maftuch (Manajer Utama PT. Buya Barokah), Kudus: di kantor PT. Buya Barokah, tanggal 17 Maret 2019. 
sudah dibacakan 30 juz Alquran serta dipercaya memiliki khasiat untuk kesehatan.

\section{Struktur Organisasi pada PT. BUYA BAROKAH Kudus}

Organisasi sangat penting dan sangat berperan demi tercapainya tujuan suatu perusahaan. Hal ini sangat diperlukan agar kinerja perusahaan lebih terarah sesuai dengan tujuan perusahaan. Selain itu organisasi diperlukan pembagian tugas seimbang dan objektif, yaitu memberikan tugas sesuai dengan kedudukan dan kemampuan setiap individu. Dalam rangka pencapaian tujuan, struktur organisasi hendaknya disesuaikan dengan keadaan dan kebutuhan. Adapun yang dimaksud struktur organisasi disini adalah seluruh tenaga yang berkecimpung dalam kepengurusan PT. Buya Barokah Kudus. Adapun struktur organisasi PT. Buya Barokah Kudus adalah sebagai berikut:

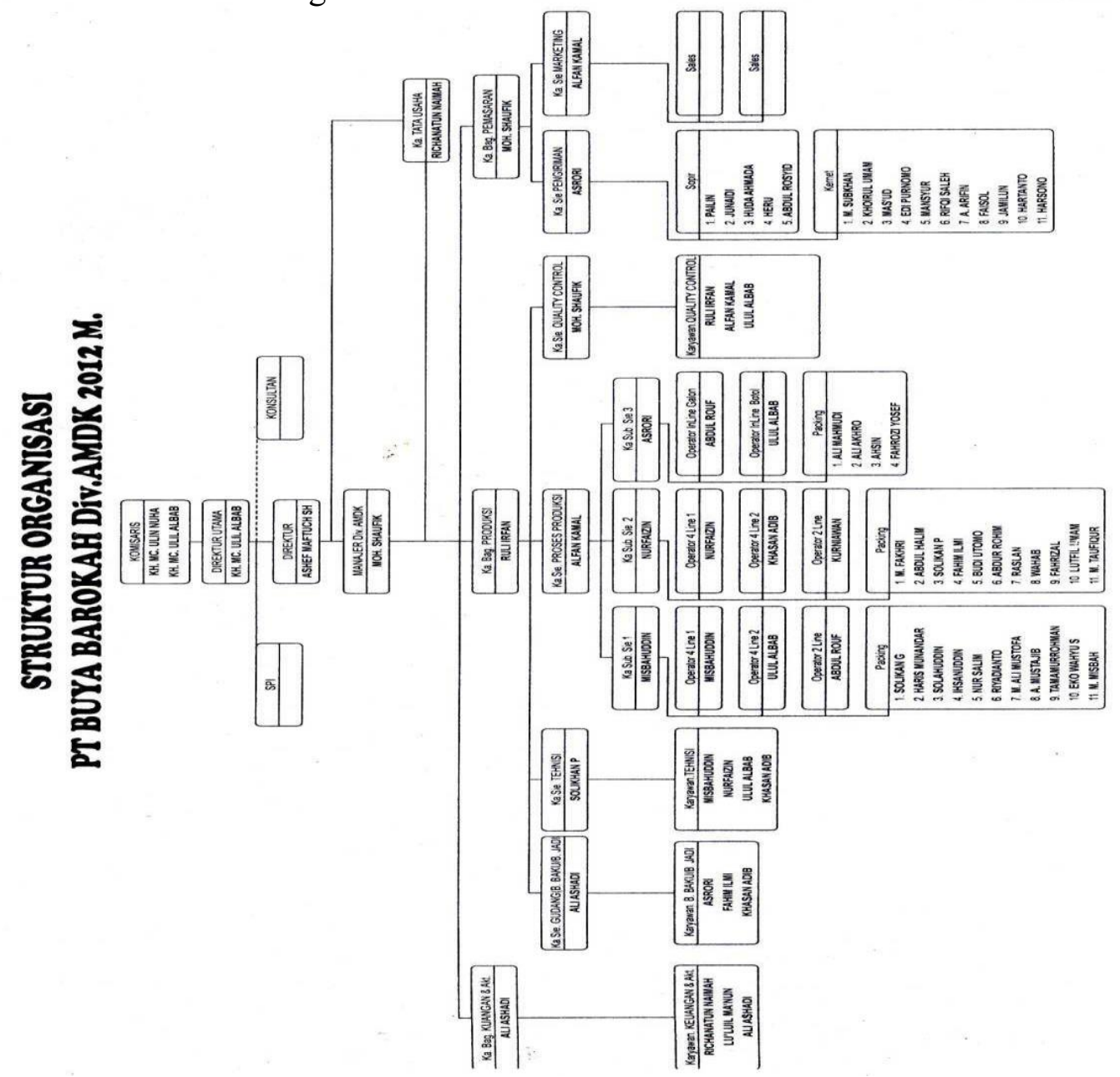

Gambar 4.1: Struktur PT Buya Barokah Dev. Air Minum 


\section{Analisis Teori Komoditas Agama}

Sebagaimana dijelaskan di atas, bahwa suatu yang mempunyai proses yang melibatkan perubahan atau transformasi menjadi produk yang dapat dipasarkan bisa dikatakan bentuk dari komoditas. Air kemasan yang diproduksi PT. Buya Barokah adalah salah satu gambaran yang jelas, bahwa air yang dapat dikonsumsi setiap manusia telah dirubah dan ditransformasi bukan hanya dikonsumsi melainkan dapat dipasarkan. Berkembangnya sosial yang selalu bersinggungan dengan agama, keduanya telah menjadi sebuah paradigma baru. Agama tidak dapat lepas dari peran sosial, sebab keduanya telah dibentuk dari sebuah konstruksi historis dan kultural yang kompleks untu mempertegas signifikansi simbolik sosio-ekonomi. Proses ini benarbenar dimunculkan dalam saluran ekonomi pasar lokal-global dan ledakan agama postmodern. Paradigma ini tidak bertujuan memproduksi bentuk dan gerakan baru yang berlawanan dengan sebuah keyakinan dan praktik-praktik agama, namun komodifikasi akan mendudukan agama sebagai barang yang melaluinya fungsi spiritual agama menjadi komoditas yang layak dikonsumsi oleh masyarakat umum.

PT. Buya Barokah telah mendudukkan agama, melalui pembacaan (khataman) Alquran pada salah satu produksinya. Air Kh-Q yang merupakan produk dari PT. Buya Barokah telah mempunyai peran ganda. Air tersebut bukan hanya bersirkulasi pada ekonomi, akan tetapi ada fungsi spiritual dalam dirinya sebagai air doa. Dalam hasil wawancara dengan orang yang bersangkutan, memang benar adanya air kemasan dalam brand Kh-Q ini sebagai sebuah bentuk perantara (ngalap berkah) kepada Allah Swt. supaya dijauhkan dari segala penyakit. Demikian adalah sebuah dekonstruksi komoditas dalam menentukan apa makana yang tampak, untuk membongkar relasi-relasi sosial yang membeku dalam bentuk komoditas.

Promosi dari mulut ke mulut dan ada bacaan Alquran menjadi media paling cepat dan memiliki posisi tawar yang menjanjikan, wajar jika produk Kh-Q walaupun belum lama produksinya, namun cepat melekat di hati warga, tak heran jika sejumlah toko sembakao atau warung kelontong di wilayah Kudus, Jepara, Demak menyediakan air kemasan ini dan harga eceranpun berani sama dengan merk seperti Aqua atau Vit, bahkan warga lebih melirik merk Kh-Q. Pernyataan di atas, merupakan bentuk yang dapat dikatakan sebagai peran Alquran yang signifikan, bahwa Alquran mempunyai daya tarik bagi pembeli, sehingga dalam ekonomi sendiri dapat meningkat lebih banyak dan berkeuntungan yang melimpah. Bukti lain, terdapat pada kemasan air itu sendiri, bahwa nama Kh-Q adalah singkatan dari Khataman Alquran. Dalam label air kemasan juga terdapat beberapa indikasi agama, seperti perintah untuk berdoa sebelum meminum air Kh-Q. Menurut penulis, inti dari adanya tulisan tersebut ialah bagaimana agama tersalurkan melalui sebuah produksi air mineral. Meski tidak menutup 
kemungkinan lain, bahwa demikian dapat menarik pelanggan untuk membeli produk tersebut.

\section{SIMPULAN}

Dari paparan di atas, ada beberapa hal yang dapat disimpulkan. Pertama, prosesi pembuatan air kemasan oleh PT. Buya Barokah yang bediri sejak tahun 2008 telah memberi innovasi lain dengan bentuk pembacaan Alquran. Demikian adalah sebab dari keprihatinan sosial yang kemudian terealisasi untuk memenuhi kebutuhan masyarakat.

Kedua, sebagai cerminan atas beragamnya tipe pembacaan Alquran khususnya di Indonesia. pembacaan Alquran pada produksi air kemasan di masa sekarang bisa dibilang masih jarang. Sedikit memberikan gambaran pada proses pembacaan Alquran. Telah disediakan beberapa galon yang telah terisi air secara melingkar. Pada proses yang dilakuan di makam mbah Arwani dilakukan ketika ada event tertentu, sebab nantinya air akan dibagikan sebagian kepada para tamu yang hadir di sebuah acara dan sebagian lain dimasukkan ke dalam sumur produksi air. Adapun proses khataman yang dilakukan di tempat produksi, dilakukan setiap hari secara bergantian.

Ketiga, peran agama yang dipadukan dengan tindak sosial masyarakat dapat merubah dan mentransformasi sebuah nilai tular menjadi nilai guna. Sebagai bukti pembacaan Alquran dalam Air Kemasan Kh-Q merupakan bentuk komoditas dan peran agama. Komoditas bergerak menjadikan sesuatu berubah dan tertransformasi pada bentuk atau suatu yang lain. PT. Buya Barokah telah mendudukkan agama, melalui pembacaan (khataman) Alquran pada salah satu produksinya. Itulah cerminan bentuk dari komodifikasi agama.

\section{DAFTAR PUSTAKA}

Akhmad, Idi Subandy Ibrahim, dan Bachruddin Ali. Komunikasi dan Komodifikasi: Mengkaji Media dan Budaya dalam Dinamika. Jakarta: Yayasan Putra Obor Indonesia, 2014.

Dimyati, Ahmad. Dakwah Personal: Model Dakwah Kaum Naqsyabandiyah Yogyakarta: Deepublish, 2016.

Esack, Farid. The Quran: a Short Introduction. London: Oneworld Publication, 2002.

. The Qur'an: A User's Guide : a Guide to Its Key Themes, History and Interpretation. T.tp: Oneworld, 2005.

Junaedi, Didi. "Memahami Teks, Melahirkan Konteks." Journal of Alquran and Hadith Studies Vol.3, No. 1 (2013):

Nasution, Harun. Islam ditinjau dari dari berbagai Aspeknya. Jakarta: Universitas Indonesia Press, 1985. 
Nurawalin, Vitri. Pembacaan Alquran dalam Tradisi Mujahadah Sabihah Jumu'ah :Studi Living Qur'an di Pondok Pesantren Sunan Pandanaran, Sleman, Yogyakarta. Yogyakarta: Fakultas Ushuluddin UIN Sunan Kalijaga, 2014.

Rafi'uddin. Pembacaan Ayat-Ayat Alquran dalam Upacara Peret Kandung di desa Poteran Kec. Talango kab. Sumenep Madura. Yogyakarta: Fakultas Ushuluddin UIN Sunan Kalijaga, 2013.

Wawancara dengan bpk Ashef Maftuch (Manajer Utama PT. Buya Barokah), Kudus: di kantor PT. Buya Barokah, tanggal 17 Maret 2019.

Wawancara dengan Saudara Abdurrahman Wahid (santri ponpes Yanbu'ul Quuan), pada tanggal 17 Maret 2019.

Wasik, Moh Ali. Fenomena Pembacaan Alquran dalam masyarakat Padukuhan Srumbung, Pleret, Bantul. Yogyakarta: Ushuluddin UIN Sunan Kalijaga, 2005.

http://www.arwaniyyah.com/index.php/2012-06-05-18-59-41/123-profil-yayasanarwaniyyah. rabu, 12 Maret 2019.

https://www.kompasiana.com/penaulum/5b27118fbde57517e3046eb2/berkahbacaan-alquran-di-air-kemasan-Kh-Q. diakses pada Tanggal 25 Mei 2019. 